GASTRIC CANCER

\title{
Insulin-like growth factor I receptor blockade enhances chemotherapy and radiation responses and inhibits tumour growth in human gastric cancer xenografts
}

\author{
Y Min, Y Adachi, H Yamamoto, A Imsumran, Y Arimura, T Endo, Y Hinoda, C-T Lee, S Nadaf, \\ D P Carbone, K Imai
}

Gut 2005;54:591-600. doi: 10.1136/gut.2004.048926

See end of article for authors' affiliations

Correspondence to: Dr Y Adachi, First Department of Internal Medicine, Sapporo Medical University, S-1, W-16, Chuo-ku, Sapporo 060-8543, Japan; yadachi@sapmed.ac.jp

Revised version received 8 December 2004 Accepted for publication 21 December 2004

\begin{abstract}
Background and aims: Insulin-like growth factor (IGF) I receptor (IGF-Ir) signalling is required for carcinogenicity and proliferation of many tumours but this pathway has not been studied in detail in gastric cancer. We have previously shown successful therapy for colorectal, pancreatic, and lung cancer using recombinant adenoviruses expressing dominant negative (dn) IGF-Ir. In this study, we sought to better dissect the role of IGF-Ir on progression of gastric cancer and determine whether IGF-Ir targeted adenoviruses represent potentially effective therapeutics for human gastric cancer.

Methods: We assessed the effect of IGF-Ir ligands on proliferation and survival in gastric cancer cells in culture. Then, recombinant adenoviruses expressing truncated IGF-Ir (482 and 950 amino acids long, IGF-Ir/dn) that function as dn inhibitors were studied in the treatment of human gastric cancer xenografts. We characterised the effects of IGF-Ir/dn on signalling blockade, growth, apoptosis induction, and in vivo therapeutic efficacy.

Results: IGF-Ir signalling promoted tumour growth and survival in gastric cancer. IGF-Ir/dn expression suppressed tumorigenicity both in vitro and in vivo and upregulated stressor induced apoptosis. IGF-Ir/dn blocked Akt-1 activation induced by IGF-I, IGF-II, and des(1-3)IGF-I, but not by insulin. IGF-Ir/ $\mathrm{dn}$ expression increased radiation and chemotherapy induced apoptosis and the combination of IGF-Ir/dn and chemotherapy was very effective against tumours in mice. In an intraperitoneal model, IGF-Ir/dn therapy also suppressed peritoneal dissemination.

Conclusions: IGF-Ir is involved in the regulation of survival and cell growth in human gastric cancer and may be a good molecular therapeutic target. Adenovirus-IGF-Ir/dn may thus have therapeutic use in gastric cancer.
\end{abstract}

S everal growth factor receptors with intrinsic tyrosine kinase activity play key roles in the development and progression of neoplasia. Among these are the insulinlike growth factors (IGFs) that can stimulate cellular proliferation and differentiation. ${ }^{1}$ The IGF-I receptor (IGFIr) is a heterodimer of $\alpha$ and $\beta$ chains. ${ }^{2}$ Binding of the ligands (IGF-I and IGF-II) to IGF-Ir causes receptor autophosphorylation and leads to activation of multiple signalling pathways such as the mitogen activated protein kinase (MAPK)/ extracellular signal regulated kinase (ERK) and phosphatidylinositide-3-kinase (PI3-K)/Akt-1 pathways. ${ }^{3}{ }^{4}$ IGF-Ir is important for maintenance of the malignant state as well as initiation of transformation. ${ }^{56}$ Reduction of IGF-Ir induces apoptosis in tumours but produces only growth arrest in untransformed cells. ${ }^{7}$ IGF-Ir-knockout mice are viable (although physically smaller than normal), indicating that relatively normal development and tissue differentiation as well as essential tissue functions in the adult animal occur in its absence. ${ }^{8}$ These findings suggest a potential basis for tumour selectivity in therapeutic applications.

In the human fetus, the stomach contains the highest level of IGF-I mRNA. ${ }^{9}$ The mitotic influence of IGF-II appears to be regulated by IGF binding protein (IGFBP) isoforms in fetal gastric mucosa. ${ }^{10}$ Moreover, IGF-I promotes gastric ulcer healing via stimulating cell proliferation. ${ }^{11}$ These data suggest that the IGF/IGF-Ir axis may be implicated in the organogenesis, growth, and homeostasis of the stomach.

Serum levels of IGFs and IGFBP3 in patients with gastric cancer were decreased after gastrectomy. ${ }^{12}{ }^{13}$ Expression of IGF-II and IGF-Ir was increased in cancer tissue. ${ }^{14-16}$ The level of IGF-II correlated with DNA synthesis, proliferation, and lymphatic vessel infiltration. ${ }^{16}{ }^{17}$ IGFs stimulated proliferation of cancer cells which was inhibited by anti-IGF-Ir antibody. ${ }^{15} 1618$ IGF receptor 2 (IGF-2r) may be involved in the clearance of IGF-II from the circulation and may function as a tumour suppressor. However, when mutated, IGF-2r loses its anti-oncogenic activity. These findings suggest that the IGF family is involved in the pathogenesis of gastric cancer, probably by autocrine/paracrine stimulation of cell growth. However, other roles for IGF-Ir have not been studied in detail.

There are several ways of blocking receptor signalling. Dominant negative $(\mathrm{dn})$ receptors are unique in that they inhibit the function rather than expression of wild-type receptor. There are two major ways of constructing $\mathrm{dn}$ inhibitors of IGF-Ir. One approach is formation of receptors having either a mutant or deleted intracellular tyrosine
Abbreviations: IGF, insulin-like growth factor; IGF-Ir, insulin-like growth factor I receptor; IGFBP, insulin-like growth factor binding protein; IGF-2r, insulin-like growth factor receptor 2; dn, dominant negative; IGF-Ir/dn, dominant negative form of IGF-Ir; IGF-Ir/482st, truncated IGF-Ir of 482 amino acids long; IGF-Ir/950st, truncated IGF-Ir of 950 amino acids long; Ad-IGF-Ir/482st, adenoviruses expressing IGF-Ir/482st; Ad-IGF-Ir/950st, adenoviruses expressing IGF-Ir/950st; des(1-3)IGF-I, NH2 terminally truncated IGF-I; MAPK, mitogen activated protein kinase; ERK, extracellular signal regulated kinase; $\mathrm{PI} 3-\mathrm{K}$, phosphatidylinositide 3-kinase; moi, multiplicity of infection; 5-FU, 5-fluorouracil; RT-PCR, reverse transcription-polymerase chain reaction; SDS-PAGE, sodium dodecyl sulphate-polyacrylamide gel electrophoresis; Ad-LacZ, adenovirus expressing $\beta$-galactosidase 
kinase domain. ${ }^{19-21}$ Another is construction of a receptor comprised of only the extracellular domain..$^{22}{ }^{23}$ We made two truncated IGF-Ir constructs (950 and 482 amino acid residue IGF-Irs-IGF-Ir/950st and IGF-Ir/482st, respectively). ${ }^{24}$ The former produces intact $\alpha$ subunit and defective $\beta$ subunit lacking the tyrosine kinase domain and was hypothesised to remain on the membrane of the transduced cells and form non-functional heterodimers. The latter has a defective $\alpha$ chain without a transmembrane domain and thus should result in a secreted form that may affect neighbouring cells in addition to transduced cells. We previously reported that IGF-Ir/dn may be a useful therapeutic strategy for colorectal, pancreatic, and lung cancers and may be more effective than antisense approaches. ${ }^{24-26}$

As gastric cancer is a heterogeneous disease, it is important to evaluate the universality of the position of the IGF/IGF-Ir axis. In this study, we examined the roles of this axis on carcinogenesis, proliferation, and survival in several human gastric cancer cell lines. Then we assessed the impact of IGF-Ir/dn on signalling blockade, growth, apoptosis induction, and in vivo therapeutic efficacy in subcutaneous and intraperitoneal xenografts. These observations strengthen the rationale for using dn IGF-Ir gene therapy alone or in combination with chemotherapy or radiotherapy in the molecular targeted therapy of gastric cancers.

\section{MATERIALS AND METHODS \\ Materials, cell lines, and mice}

Anti-Aktl(c-20), anti-ERKl(K-23), anti-phospho-ERKl(E-4), and anti-IGF-Ir $\alpha(2 \mathrm{C} 8)$ were purchased from Santa Cruz Biotechnology (Santa Cruz, California, USA) and antiphospho-Akt(Ser473), anti-p38, anti-phospho-p38(Thr180/ Tyr182), anti-Bad, anti-phospho-Bad(Ser112), anti-caspase-3, and anti-cleaved-caspase-3(Asp175) from Cell Signaling Technology (Beverly, Massachusetts, USA). PI3-K inhibitor wortmannin, p38-MAPK inhibitor SB203580, and 5-fluorouracil (5-FU) were purchased from Sigma (St Louis, Missouri, USA), and MEKl inhibitor PD98059 from Cell Signaling. Recombinant human IGF-I and IGF-II were purchased from R\&D systems (Minneapolis, Minnesota, USA) and NH2 terminally truncated IGF-I (des(1-3) IGF-I) from GroPep (Adelaide, Australia). All human gastric cancer cell lines were obtained from the Japanese Cancer Collection of Research Bioresources Cell Bank (Tokyo, Japan). Cells were passaged in RPMI1640 and DMEM both with 10\% fetal bovine serum. Specific pathogen free female BALB/CAnNCrj-nu mice, six weeks old, were purchased from Charles River (Yokohama, Japan). The care and use of mice were according to our university's guidelines.

\section{Recombinant adenovirus vectors}

Recombinant adenovirus vectors were performed as described previously. ${ }^{24}{ }^{26}$ Recombinant adenoviruses expressing the two truncated IGF-Ir constructs (IGF-Ir/950st and
IGF-Ir/482st) were designated Ad-IGF-Ir/dns (Ad-IGF-Ir/ 482st and Ad-IGF-Ir/950st, respectively). An adenovirus expressing $\beta$-galactosidase was used as a control (Ad-LacZ).

\section{Reverse transcription-polymerase chain reaction (RT-PCR)}

Total RNA from cells was isolated using the acid guanidinium thiocyanate-phenol-chloroform method. Randomly primed cDNAs were prepared from $1 \mu \mathrm{g}$ of total RNA by M-MLV reverse transcriptase (Takara, Japan) and amplified by PCR. The sequences for the primers and the conditions for their use are summarised in table $1 .^{27-29}$

\section{Western blotting}

Cells were treated as indicated in the text. Cell lysates were prepared as described previously. ${ }^{24}$ Equal aliquots of lysate (100 g) were separated by $10 \%$ sodium dodecyl sulphatepolyacrylamide gel electrophoresis (SDS-PAGE) and immunoblotted onto polyvinylidene Hybond-P membrane (Amersham, Arlington Heights, Illinois, USA). Analysis was performed using indicated antibodies, and bands were visualised by ECL (Amersham).

\section{p38-MAPK kinase activity assay}

p38 kinase assay was performed following the manufacturer's protocol (p38-MAP kinase assay kit; Cell Signaling). In brief, protein extracts in cell lysis buffer were immunoprecipitated with anti-p38. Samples were incubated with $50 \mu \mathrm{l}$ of kinase buffer supplemented with ATF2 fusion protein. Samples were loaded in SDS-PAGE.

\section{In vitro cell growth}

Tumour cells were grown to $70 \%$ confluence in six well plates and infected with adenoviruses. The number of cells were then assayed by trypan blue staining.

\section{Tumorigenicity in vivo}

One $\times 10^{6}$ MKN45 infected with adenoviruses were inoculated subcutaneously into the murine hip region. Tumour diameters were serially measured with callipers and tumour volume was calculated using the formula: tumour volume $\left(\mathrm{mm}^{3}\right)=\left(\right.$ width ${ }^{2} \times$ length $) / 2$.

\section{Assessment for apoptosis}

Caspase-3 colorimetric protease assay was performed following the manufacturer's protocol (Caspase-3 Colorimetric Protease Assay Kit; MBL, Nagoya, Japan). In brief, $5 \times 10^{6}$ cells were lysed in $250 \mu \mathrm{l}$ of cell lysis buffer, and caspase-3 activity of lysates $(100 \mu \mathrm{g})$ was measured by colorimetric reaction at $400 \mathrm{~nm}$. Active caspase- 3 was measured by flow cytometry using CaspGLOW fluorescein active-caspase-3 staining kit (MBL). Early apoptosis were quantified by staining with annexin V-FITC, according to the manufacturer's protocol

Table 1 Polymerase chain reaction primers and annealing temperatures used

\begin{tabular}{|c|c|c|c|c|}
\hline Gene & Primer & $\begin{array}{l}\text { Annealing } \\
\text { temp ( }{ }^{\circ} \mathrm{C} \text { ) }\end{array}$ & $\begin{array}{l}\text { Size } \\
\text { (bp) }\end{array}$ & Reference \\
\hline IGF-I & $\begin{array}{l}\text { 5'-CACTGTCACTGCTAAATTCA-3' } \\
5^{\prime} \text {-CTGTGGGCTGTTGAAATAA-3' }\end{array}$ & 60 & 396 & $\mathrm{Hana}^{27}$ \\
\hline |GF-II & $\begin{array}{l}\text { 5'-AGTCGATGCTGGTGCTTCTCA-3' } \\
\text { 5'-GTGGGCGGGGTCTIGGGTGGGTAG-3' }\end{array}$ & 60 & 468 & Quinn ${ }^{28}$ \\
\hline IGF-Ir & $\begin{array}{l}\text { 5'-ATTGAGGAGGTCACAGAGAAC-3' } \\
\text { 5'-TCATATCCTGIITGGCCTG-3' }\end{array}$ & 60 & 755 & Quinn ${ }^{28}$ \\
\hline IGF-2r & $\begin{array}{l}\text { 5'-TCAACATCTGTGGAAGTGTG-3' } \\
3^{\prime} \text {-GAATAGAGAAGTGTCCGGATCGGAGTC-5' }\end{array}$ & 62 & 430 & Bredin $^{29}$ \\
\hline
\end{tabular}

IGF-I, IGF-II, insulin-like growth factors I and II; IGF-Ir, insulin-like growth factor I receptor; IGF-2r, insulin-like growth factor receptor 2 . 

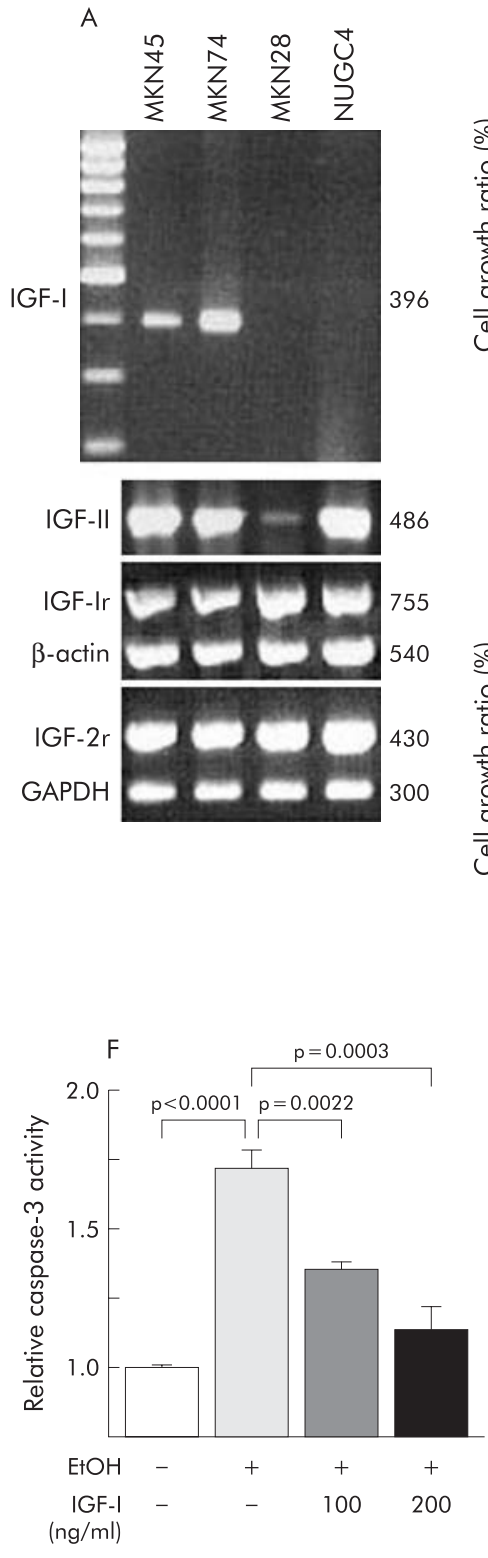

(BD Biosciences, Franklin Lakes, New Jersey, USA) and measured by flow cytometry. Cells undergoing apoptosis showed an increase in annexin $\mathrm{V}$ binding but excluded propidium iodide. TUNEL assays were performed with an in situ apoptosis detection kit (Takara) following the manufacturer's protocol. DNA fragmentation assay was performed as
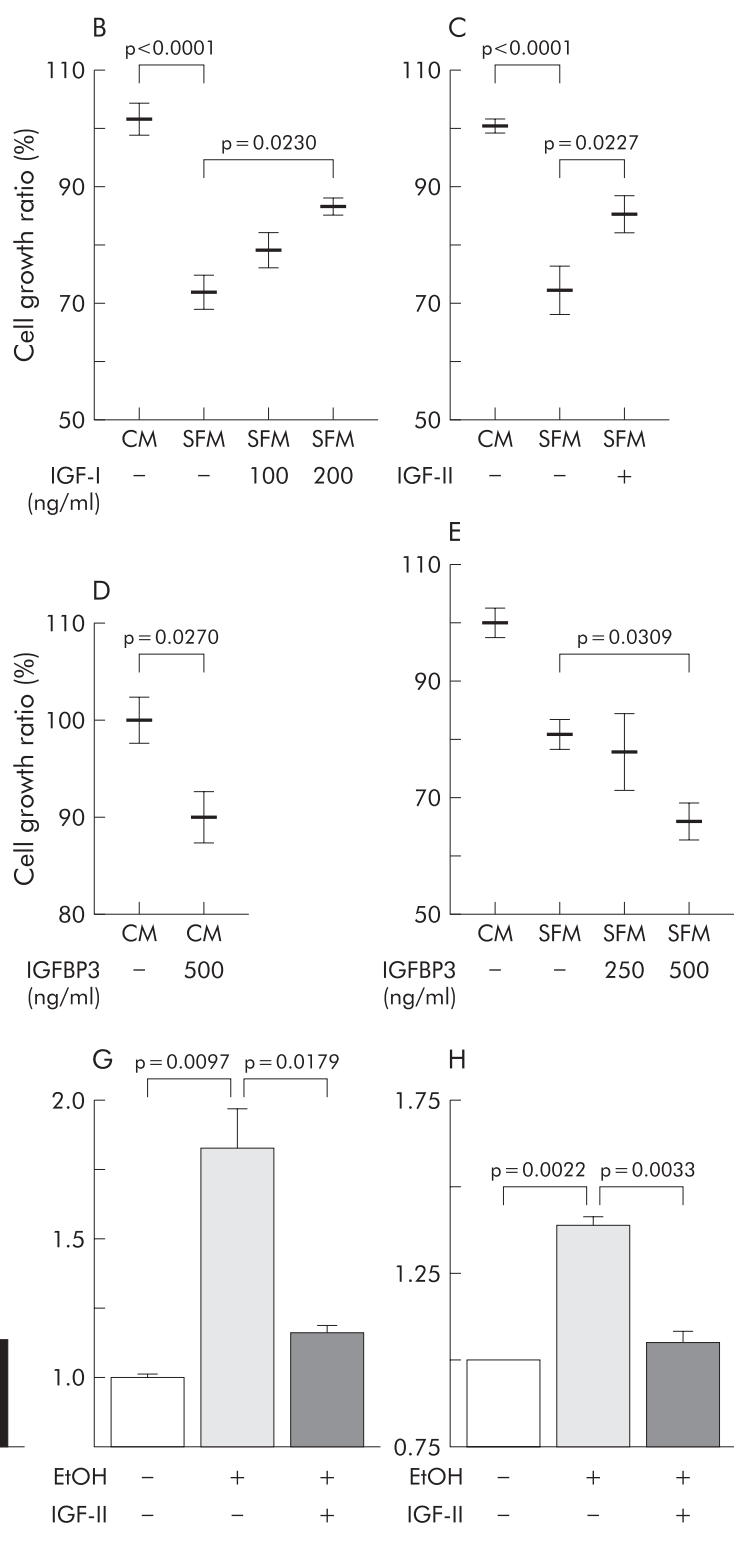

Figure 1 Expression and roles of the insulin-like growth factor/insulin-like growth factor I receptor (IGF/IGF-Ir) axis in human gastric cancer cell lines. (A) Representative data of reverse transcription-polymerase chain reaction analyses. Both MKN45 and MKN74 cells expressed IGF-I message (396 bp) but neither MKN28 nor NUGC4 showed any expression. All cells expressed mRNAs of IGF-II (468 bp), IGF-Ir (755 bp), and insulin-like growth factor receptor 2 (IGF-2r) (430 bp). Controls were $\beta$-actin $(540 \mathrm{bp})$ and GAPDH (300 bp). (B-E) After MKN45 cells were cultured to $60 \%$ confluence $\left(1 \times 10^{6}\right)$ in six well plates, medium was replaced with the indicated medium (complete medium (CM) or serum free medium (SFM)) for an additional 48 hours and then cell growth evaluated by trypan blue assay. Growth ratio was calculated compared with the cell number in complete medium with $10 \%$ fetal calf serum $(1.76$

$\left.(0.05) \times 10^{6}\right)$. Cell growth was suppressed by serum withdrawal (SFM,

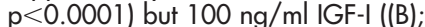
$p=0.0230$, SFM without IGF-I $v$ SFM with IGF-I) and $100 \mathrm{ng} / \mathrm{ml}$ IGF-II ((C); $p=0.0227$, SFM without IGF-II $v$ SFM with IGF-II) partially restored growth. (D) Insulin-like growth factor binding protein 3 (IGFBP3) reduced cell growth in complete medium. (E) The growth suppressing effect of IGFBP3 was also seen in serum free medium dose dependently. (F-H) Both IGF-I (F) and IGF-II (100 ng/ml (G, H)) blocked induction of $5 \%$ ethanol $(\mathrm{E}+\mathrm{OH}$ one hour) induced apoptosis in both MKN45 $(\mathrm{F}, \mathrm{G})$ and MKN74 $(\mathrm{H})$ (F) $p<0.0001$, no stimulation $v$ ethanol stimulation without IGF-I; $p=0.0003$, ethanol without IGF-I $v$ ethanol with $200 \mathrm{ng} / \mathrm{ml}$ IGF-I. (G) $p=0.0097$, no stimulation $v$ ethanol stimulation without IGF-II; $p=0.0179$, ethanol without IGF-I $v$ ethanol with IGF-I. (H) $p=0.0022$, no stimulation $v$ ethanol stimulation without IGF-II; $p=0.0033$, ethanol without IGF-I $v$ ethanol with IGF-I.

described previously. ${ }^{25}$ Low molecular weight DNA was extracted and subjected to $1 \%$ agarose gel electrophoresis.

Cells infected with adenoviruses were induced with 24 hours of serum starvation, heat shock $\left(42^{\circ} \mathrm{C} / 1 \mathrm{~h}\right)$, and $5 \%$ ethanol (one hour). Cells were treated with $260 \mu \mathrm{M}$ 5-FU or radiation (30 Gy/l1 minutes).

Table 2 Characteristics of the human gastric cancer cell lines used in this study

\begin{tabular}{|c|c|c|c|c|c|c|c|c|c|c|c|c|}
\hline & \multicolumn{12}{|l|}{ Cell line } \\
\hline & Katolll & JRST & MKN1 & MKN28 & MKN45 & MKN74 & NUGC3 & NUGC4 & SNU1 & SNU638 & GT3TKB & HGC27 \\
\hline Histological type ${ }^{*}$ & SRC & SRC & ASC & DA & UDA & DA & PDA & SRC & $A C$ & $A C$ & AC & UDA \\
\hline p53† & $\mathrm{mt}$ (loss) & $?$ & $\mathrm{mt}$ & $\mathrm{mt}$ & $\mathrm{WT} / \mathrm{mt}$ & $\mathrm{mt}$ & $\mathrm{mt}$ & WT & WT & $\mathrm{mt}$ & $?$ & $?$ \\
\hline IGF-I & + & + & - & - & + & + & - & - & \pm & \pm & - & - \\
\hline IGF-II & - & \pm & + & \pm & + & + & \pm & + & \pm & \pm & - & + \\
\hline IGF-Ir & + & + & + & + & + & + & + & + & + & + & - & \pm \\
\hline IGF- $2 r$ & + & + & + & + & + & + & + & + & \pm & + & + & \pm \\
\hline
\end{tabular}

*AC, adenocarcinoma; ASC, adenosquamous carcinoma; DA, differentiated adenocarcinoma; PA, poorly differentiated adenocarcinoma; SRC, signet ring cell carcinoma; UDA, undifferentiated adenocarcinoma.

tmt, mutant-type; WT, wild-type; ?, no information.

+ , strong expression; \pm , weak expression; - , no expression. 

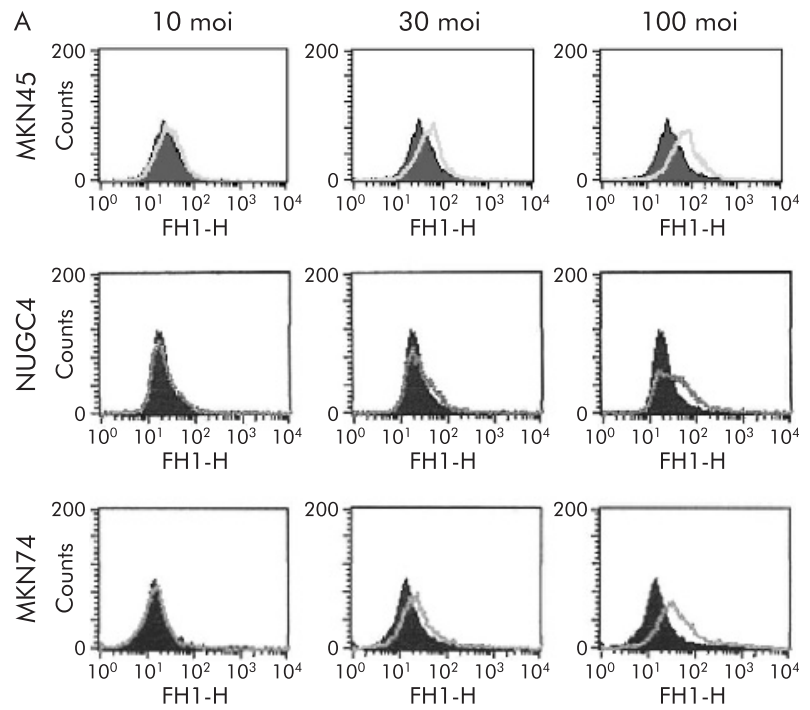

B
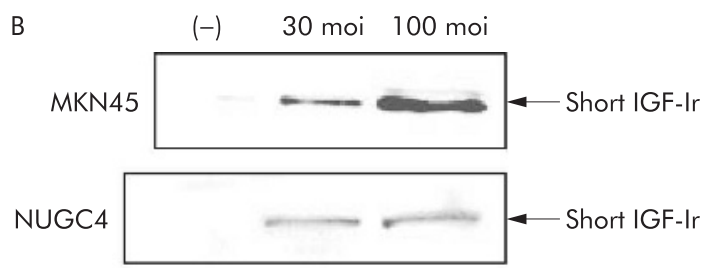

MKN74

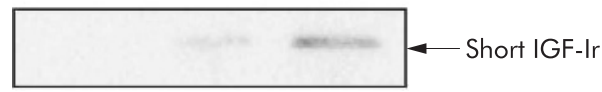

Figure 2 Adenovirus induced expression of the dominant negative (dn) form of insulin-like growth factor I receptor (IGF-Ir/dn) in three human gastric cancer cell lines. (A) MKN45, NUGC4, and MKN74 cells expressed dose dependently $\alpha$ chains of IGF-Ir after infection with adenoviruses expressing truncated IGF-Ir of 950 amino acids long (AdIGF-Ir/950st). (B) Equal aliquots of culture medium were collected and concentrated 50 times before undergoing 10\% sodium dodecyl sulphatepolyacrylamide gel electrophoresis. Western blotting showed that the three cell lines infected with adenoviruses expressing truncated IGF-Ir of 482 amino acids long (Ad-IGF-Ir/482st) secreted a short IGF-Ir into the medium.

\section{In vivo therapeutic efficacy in established tumours}

One $\times 10^{6}$ MKN45 were subcutaneously injected into 36 nude mice. After all tumours were palpable (20 days after inoculation), $1 \times 10^{8} \mathrm{PFU}$ of adenoviruses were injected intratumorally daily for five consecutive days. Mice were killed on day 41 when tumours began to cause clinically evident disability.

We evaluated the effect of adding Ad-IGF-Ir/482st to chemotherapy of established tumours. After all MKN45 tumours were palpable (on day 24), $1 \times 10^{8}$ PFU of adenoviruses were injected intratumorally for five days. Both groups were then divided into pair matched chemotherapy treated and control groups $(\mathrm{n}=12$ /group) and 5-FU $(50 \mathrm{mg} / \mathrm{kg}$ ) or vehicle was administered intraperitoneally once per week for four doses.

\section{Therapeutic efficacy of peritoneal dissemination}

One $\times 10^{6}$ MKN45 were injected into the peritoneal cavities of 35 nude mice. Three days later, 50 multiplicity of infection (moi) (based on the injected cell number) of adenoviruses were injected intraperitoneally daily for five days. Five mice in each group were killed on day 26, at which time the first mouse appeared clinically symptomatic. Other mice were carefully observed everyday until they developed significant clinical incapacity.

\section{Statistical analysis}

Results are presented as means (SEM) for each sample. The statistical significance of differences was determined by the Student's two tailed $t$ test in two groups and by one way ANOVA in multiple groups with two factor factorial ANOVA. Survival curves were constructed according to the method of Kaplan-Meier. A p value of less than 0.05 was considered significant.

\section{RESULTS}

\section{mRNA expression of the IGFs and their receptors}

In order to investigate the roles of the IGF/receptor axis, we examined mRNA expression patterns for the IGF family in 12 gastric cancer cell lines using RT-PCR. Figure 1A shows representative data and the results are summarised in table 2. Six lines expressed IGF-I mRNA (including two with weak expression). IGF-II message was expressed strongly in five cells and weakly in five. IGF-Ir message was identified in 11 cells ( 10 strong and one weak expression). All cells expressed IGF-2r mRNA. These results suggest that IGF receptors are almost universally expressed in gastric cancer. We selected three cell lines, MKN45, MKN74, and NUGC4, for the following experiments as these lines expressed IGF-Ir and had differences in other characteristics such as histological type and mutation status of p53 (table 2). ${ }^{30}$

\section{Role of the IGF-Ir axis in cancer cell proliferation and survival}

To study the role of the IGF/IGF-Ir axis on proliferation, trypan blue dye exclusion assays were performed on MKN45 cultured for 48 hours in complete or serum free media with or without ligands or IGFBP3. Proliferation was suppressed by serum starvation but IGF-I partially restored growth in a dose dependent manner (fig 1B). IGF-II also stimulated proliferation to some degree (fig IC). Conversely, IGFBP3 suppressed proliferation in both conditioned and serum free media (fig ID, E), indicating that IGFBP3 might block not only exogenous ligands but also IGF autocrine loops. These results suggest a role for the IGF axis in gastric cancer proliferation.

To evaluate the effects of IGF/IGF-Ir on survival, a caspase-3 colorimetric protease assay was performed. Treatment with $5 \%$ ethanol induced caspase- 3 activity in MKN45 and addition of IGF-I dose dependently protected cells from this effect (fig IF). IGF-II blocked ethanol induced apoptosis almost completely in both MKN45 and MKN74 (figlG, H). The results indicate that the IGFs are also involved in the regulation of apoptosis and survival in gastric cancer.

\section{Adenoviral induction of truncated IGF-Ir cDNA}

As expected, expression of the adenovirus transduced truncated receptor increased with increasing dose of two Ad-IGF-Ir/dns (moi 10-100) (fig 2A, B). FACS analysis revealed that IGF-Ir/950st was detected on the cell surface. However, as predicted, IGF-Ir/482st was not (data not shown) as this was designed to be a soluble form and was detectable in culture media by western blotting. The presence of this soluble receptor in the medium suggests the possibility of bystander effects.

\section{Signal transduction by IGF-Ir}

In MKN45, Akt-l was clearly phosphorylated with IGF-I between 10 and $200 \mathrm{ng} / \mathrm{ml}$ and with IGF-II between 5 and $100 \mathrm{ng} / \mathrm{ml}$, and this phosphorylation was observed from 5 to 25 minutes after stimulation (data not shown). The effect of $20 \mathrm{ng} / \mathrm{ml}$ IGF-I on Akt phosphorylation was equivalent to that of $10 \mathrm{ng} / \mathrm{ml}$ IGF-II, so these ligands were used at these concentrations for further experiments. IGF induced Akt phosphorylation was reduced after transduction with both 

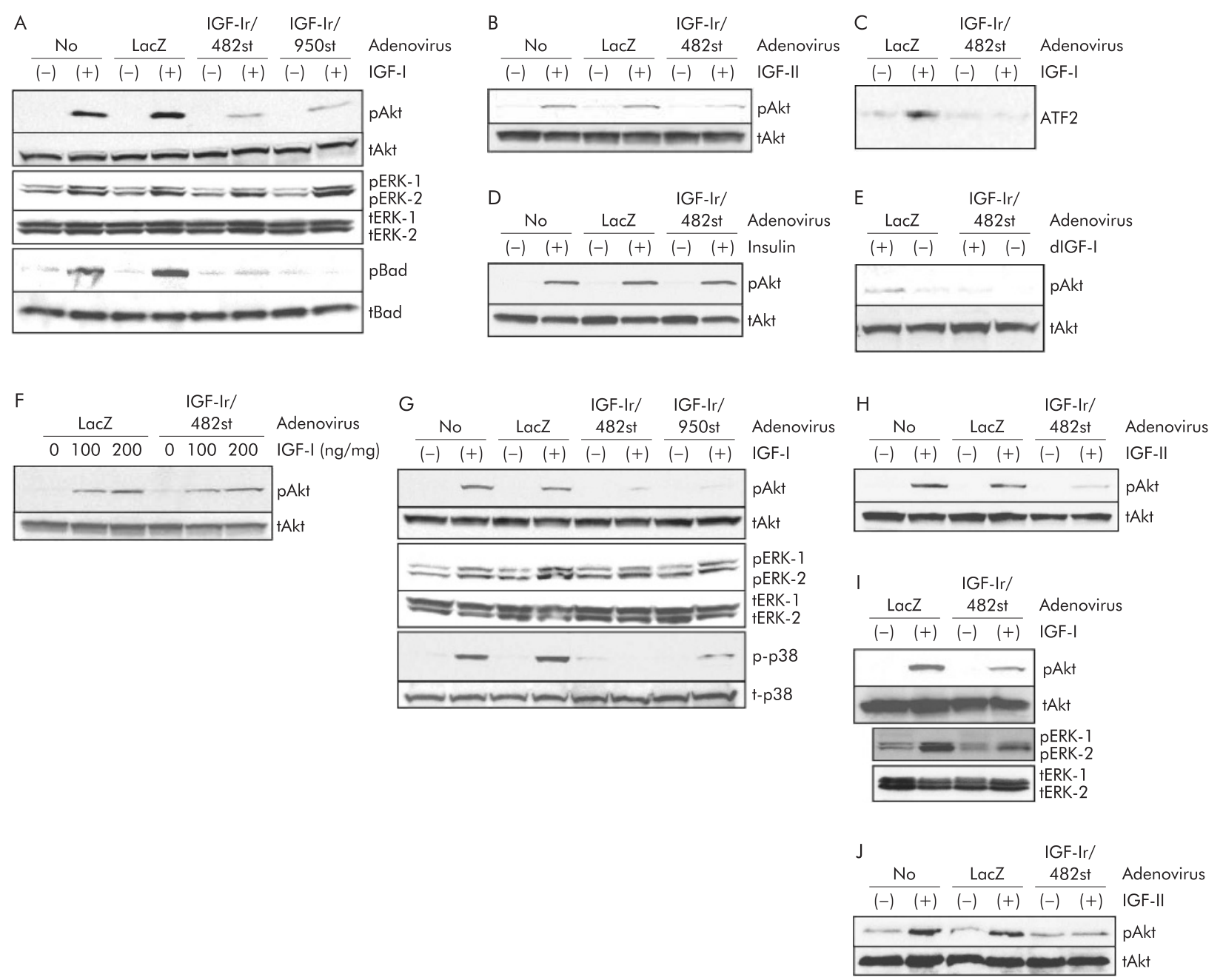

Figure 3 Downstream signals from insulin-like growth factor I receptor (IGF-Ir) in gastric cancer cells, MKN45 (A-F), NUGC4 (G, H), and MKN74 (I, J). (A) In MKN45, western blotting showed that $20 \mathrm{ng} / \mathrm{ml}$ insulin-like growth factor I (IGF-I) phosphorylated Akt-1, extracellular signal regulated kinase (ERK), and Bad. Both Akt and Bad phosphorylation was reduced by dominant negative forms (dns) of adenoviruses expressing IGF-Ir (Ad-IGFIr/dns, 30 multiplicity of infection (moi)). However, Ad-IGF-Ir/dns did not influence ERK-1/-2 phosphorylation to the same degree as Akt. pAkt, phosphorylated Akt-1; tAkt, total Akt-1; pERK, phosphorylated ERK-1/-2; tERK, total ERK-1/-2; pBad, phosphorylated Bad; tBad, total Bad. (B) Western blotting revealed that $10 \mathrm{ng} / \mathrm{ml}$ IGF-II phosphorylated Akt which was reduced by infection with adenoviruses expressing truncated IGF-Ir of 482 amino acids long (Ad-IGF-Ir/482st) (30 moi). (C) IGF-Ir/482st blocked p38 activity by p38 kinase assay. ATF2 is a substrate of p38 MAPK. (D) Insulin induces Akt phosphorylation which was not influenced by IGF-Ir/482st. (E) NH2 terminally truncated IGF-I (des(1-3)IGF-I $20 \mathrm{ng} / \mathrm{ml}$ ) phosphorylated Akt to the same degree as IGF-I. Ad-IGF-Ir/482st reduced des(1-3)IGF-I inducing Akt phosphorylation. dIGF-I, des(1-3)IGF-I. (F) IGF-Ir/482st did not block Akt phosphorylation stimulated by high dose IGF-I, especially $200 \mathrm{ng} / \mathrm{ml}$ IGF-I. (G) In NUGC4, IGF-I stimulated phosphorylation of Akt and p38 mitogen activated protein kinase (MAPK) were blocked by both IGF-Ir/dns (30 moi) but phosphorylation of ERKs were not. p-p38, phosphorylated p38 MAPK; t-p38, total p38 MAPK. (H) IGF-Ir/dn blocked IGF-II induced Akt phosphorylation. (I, J) In MKN74, IGF induced Akt phosphorylation was blocked by 100 moi of Ad-IGF-Ir/482st, but phosphorylated ERK was not. LacZ, control (adenovirus expressing $\beta$-galactosidase).

Ad-IGF-Ir/dns at 30 moi (fig 3A, B). Phosphorylation of ERK-1/-2 was influenced to a much lesser degree than Akt-1 in cells expressing the IGF-Ir/dns. IGF-I induced Bad phosphorylation was effectively blocked by IGF-Ir/dns, and a kinase assay revealed that IGF-Ir/482st abolished IGF induced p38 activity (fig 3C).

Although insulin induced Akt phosphorylation, IGF-Ir/ 482st did not block this phosphorylation (fig 3D). This indicates that IGF-Ir/dn does not affect signal transduction through the closely related insulin receptor, important for minimising toxicity in potential clinical applications. Des(13)IGF-I, an NH2 terminally truncated IGF-I with very low affinity for IGFBPs, induced Akt phosphorylation, and IGF-Ir/482st blocked this phosphorylation (fig 3E). This suggests that the effect of IGF-Ir/dn is not likely to be a consequence of altered levels of IGFBPs. High IGF-I concentrations can overcome the effect of IGF-Ir/dn on Akt phosphorylation (fig 3F), suggesting that IGF-Ir/dn works by competing with the intact receptor for ligand binding.

We then wished to evaluate this effect on other cells. In NUGC4, IGF-Ir/dns also blocked IGF induced phosphorylation of both Akt and p38 but not that of ERK (fig 3G, H). In MKN74, although 30 moi of Ad-IGF-Ir/dn had limited effects (not shown), 100 moi reduced Akt phosphorylation but not ERK (fig 3I, J). These results suggest that IGF-Ir/dn may have potency to block IGF-Ir signals, mainly Akt-l and p38MAPK, in multiple gastric cancers.

\section{IGF-Ir/dn suppressed proliferation}

To evaluate the effect of Ad-IGF-Ir/dn on cell growth, trypan blue assays were performed. Although the numbers of control cells continued to increase with time, those of cells 


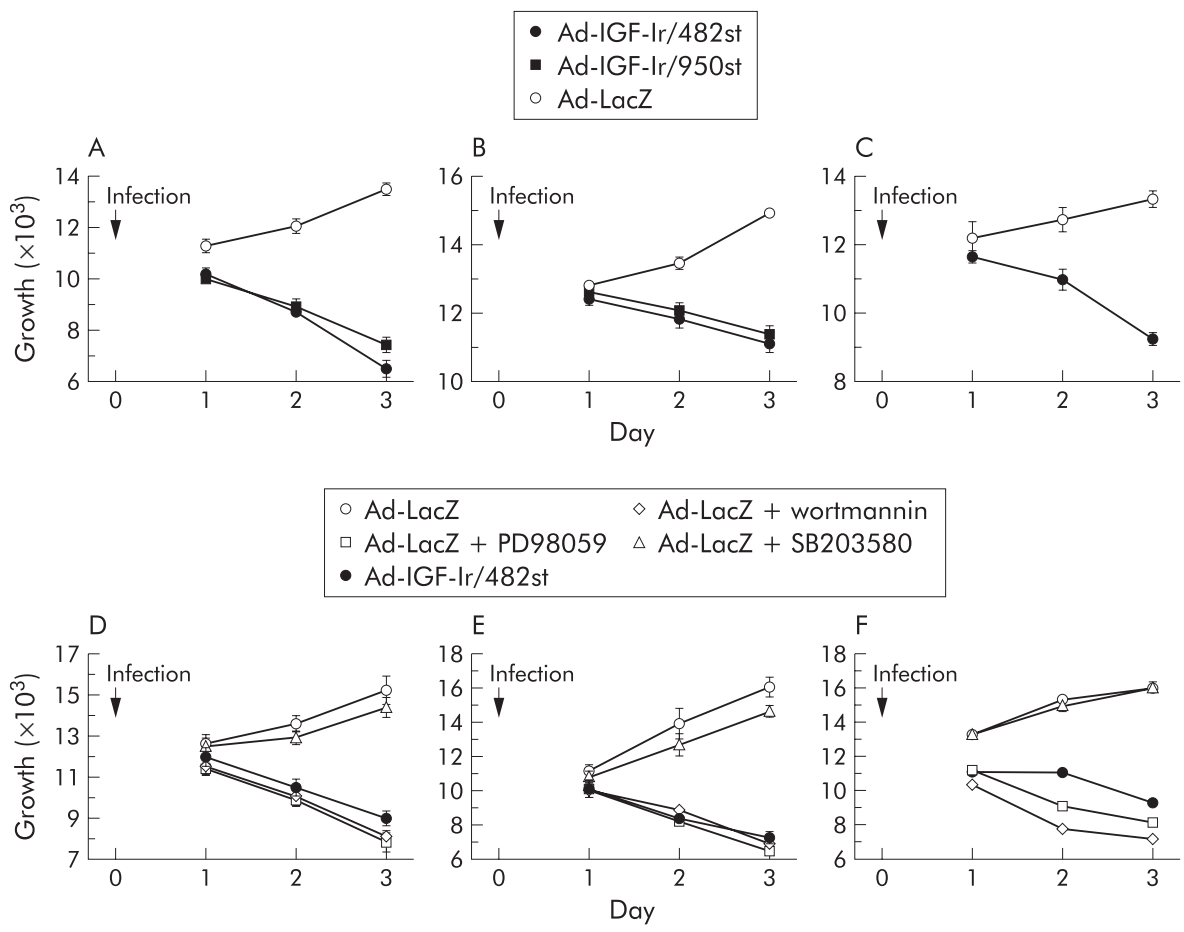

Figure 4 The role of insulin-like growth factor I receptor (IGF-Ir) on tumour proliferation. Growth of three gastric cancer cells MKN45 (A), NUGC4 (B), and MKN74 (C) infected with adenoviruses expressing truncated IGF-Ir of 482 amino acids long (Ad-IGF-Ir/482st), adenoviruses expressing truncated IGF-Ir of 950 amino acids long (Ad-IGF-Ir/950st), or control virus were evaluated by trypan blue staining. Both 30 multiplicity of infection (moi) of Ad-IGF-Ir/dns were used for both MKN45 and NUGC4 and 100 moi for MKN74. IGF-Ir/482st reduced in vitro growth in all gastric cancer cells compared with controls ((A) $p<0.0001$; (B) $p=0.0001$; and (C) $p=0.0056$ ). IGF-Ir/950st reduced proliferation in both MKN45 and NUGC4 $(p<0.0001$ and $p=0.0004$, respectively). In three cells (MKN45 (D), NUGC4 (E), and MKN74 (F)), cell growth was suppressed by PD98059 (10 $\mu M)$ and wortmannin $(200 \mathrm{nM})$ but not by SB203580 $(20 \mu \mathrm{M})$. Ad-LacZ, adenovirus expressing $\beta$-galactosidase (control). Bars show means (SEM).

expressing IGF-Ir/dns steadily decreased in all cell lines (fig 4A-C). These results confirm that the IGF-Ir signal may be essential for proliferation of gastric cancer.

To further investigate IGF-Ir downstream pathways for mitogenesis, three inhibitors were used. The effects of these inhibitors on signal blockade in MKN45 were confirmed by western blotting (data not shown). Both the PI3-K inhibitor wortmannin and the MEKl inhibitor PD98059 suppressed proliferation as effectively as Ad-IGF-Ir/482st but the p38 inhibitor SB203580 did not (fig4 D-F). Combined with the fact that IGF-Ir/dn blocked IGF inducing phosphorylation of Akt and $\mathrm{p} 38$ but not ERK, these data suggest that the antimitogenic effect of IGF-Ir/dn is mediated by inhibition of PI3-K/Akt.

\section{IGF-Ir is important for survival}

To examine the proapoptotic effects of IGF-Ir inhibition, cells infected with adenoviruses were stressed and then analysed for induction of apoptosis. Ethanol induced caspase-3 activity of MKN45 was increased after transduction with IGF-Ir/dns (table 3, fig 5A, B), which was confirmed by annexin $\mathrm{V}$ assay, tunnel assay, and DNA fragmentation assay (fig 5C-F). The result was also seen in MKN74 (table 3). IGF-Ir/dn significantly enhanced both serum starvation and heat induced apoptosis, as detected by caspase-3 assay (fig 5F, G). These results confirm that IGF-Ir is a key molecule promoting survival in gastric cancer and indicate that blockade of the receptor effectively increases apoptosis by multiple stressors.

\begin{tabular}{|c|c|c|c|c|}
\hline \multirow[b]{2}{*}{ Cell line } & \multirow[b]{2}{*}{ Adenovirus/inhibitors } & \multicolumn{2}{|c|}{ Relative caspase-3 activity (\%) } & \multirow[b]{2}{*}{ p Value* } \\
\hline & & No stimulation & $5 \%$ ethanol & \\
\hline \multirow[t]{3}{*}{ MKN45 } & Ad-LacZ & $1.00(0.01)$ & $1.38(0.03)$ & \\
\hline & Ad-IGF-Ir/482st & $1.23(0.04)$ & $1.83(0.09)^{*}$ & $0.0002^{\star}$ \\
\hline & Ad-IGF-Ir/950st & $1.21(0.07)$ & $1.78(0.05)^{*}$ & $0.0011^{*}$ \\
\hline \multirow[t]{2}{*}{ MKN74 } & Ad-LacZ & $1.00(0.03)$ & $1.72(0.02)$ & \\
\hline & Ad-IGF-Ir/950st & $1.26(0.01)$ & $1.94(0.02)^{*}$ & $0.0064^{*}$ \\
\hline \multirow[t]{2}{*}{ MKN45 } & Ad-LacZ without wortmannin & $1.00(0.01)$ & $1.36(0.04)$ & \\
\hline & Ad-LacZ with wortmannin & $1.53(0.01)$ & $1.77(0.02)^{*}$ & $0.001^{*}$ \\
\hline \multirow[t]{2}{*}{ MKN45 } & Ad-LacZ without PD98059 & $1.00(0.02)$ & $1.52(0.04)$ & \\
\hline & Ad-LacZ with PD98059 & $1.07(0.01)$ & $1.63(0.04)^{*}$ & $\mathrm{NS}^{*}$ \\
\hline \multirow[t]{2}{*}{ MKN45 } & Ad-LacZ without SB203580 & $1.00(0.02)$ & $1.77(0.05)$ & \\
\hline & Ad-LacZ with SB203580 & $1.09(0.07)$ & $1.92(0.01)^{*}$ & $N S^{*}$ \\
\hline \multicolumn{5}{|c|}{$\begin{array}{l}\text { Values are mean (SEM). } \\
\text { Ad-LacZ, control (adenovirus expressing } \beta \text {-galactosidase); Ad-IGF-Ir/482st, adenoviruses expressing truncated } \\
\text { IGF-Ir of } 482 \text { amino acids long; Ad-IGF-Ir/950st, adenoviruses expressing truncated IGF-Ir of } 950 \text { amino acio } \\
\text { long. } \\
{ }^{*} \text { Compared with cells infected with Ad-LacZ stimulated with } 5 \% \text { ethanol. }\end{array}$} \\
\hline
\end{tabular}


A

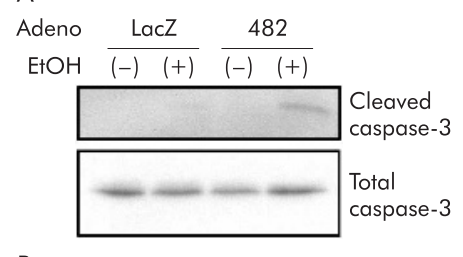

B

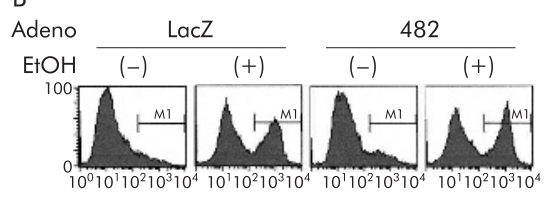

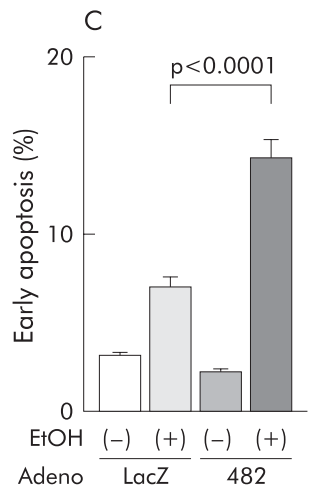

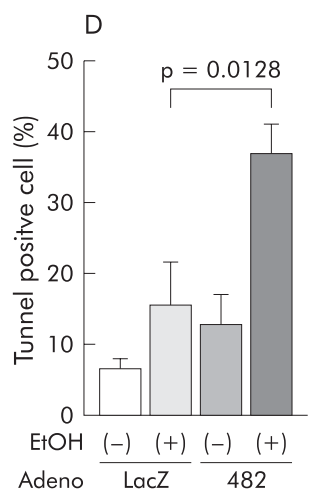

E
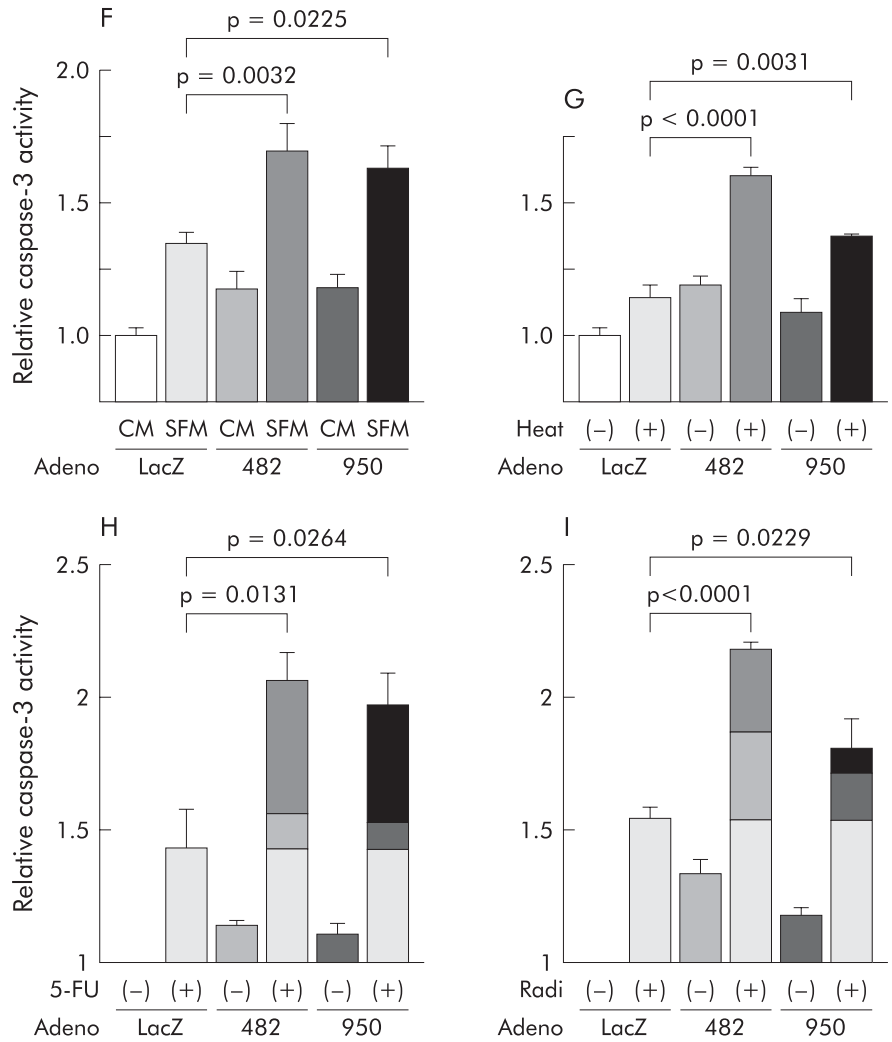

Figure 5 Role of insulin-like growth factor I receptor (IGF-Ir) in resistance to apoptosis in MKN45. Adenoviruses (30 multiplicity of infection (moi)) were used in this experiment. (A) Western blotting showed that cleaved caspase-3 was detected most in cells expressing truncated IGF-Ir of 482 amino acids long (IGF-Ir/482st (482)) and stimulated with ethanol (EłOH 5\%, 1 h). LacZ, adenovirus expressing $\beta$-galactosidase (control). (B) FACS analysis revealed that active caspase-3 was $7 \%$ in control cells without stimulation, $39 \%$ in those with ethanol, $12 \%$ in IGF-Ir/482 expressing cells (482) without stimulation, and $43 \%$ in those with ethanol. (C) The percentage of ongoing apoptosis induced by ethanol was increased by expression of the truncated receptor ( $p<0.0001$ ), as detected by annexin $V$ assay. (D) Tunnel assay showed that ethanol induced apoptosis was upregulated in cells infected by the dominant negative $(\mathrm{dn})$ form of adenoviruses expressing IGF-Ir (Ad-IGF-Ir/dn) $(p=0.0128)$. (E) DNA fragmentation assays showed increased ethanol induced apoptosis in cells expressing the shorter receptor (lane 5). Cells were infected with Ad-LacZ (lanes 2, 3) or adenoviruses expressing truncated IGF-Ir of 482 amino acids long (Ad-IGF-Ir/482st) (lanes 4,5) and were stimulated with ethanol (lanes 3, 5) or not (lanes 2, 4). Lane 1 contains a size marker. (F) Caspase-3 assay demonstrated apoptosis induction by 24 hours of serum starvation (serum free medium (SFM)). CM, complete medium. Both IGF-Ir/482st (482) and IGF-Ir/950st (950) upregulated starvation induced apoptosis $1.70(0.10)$ and $1.63(0.08)$ times, respectively, and the former was more effective than the latter $(p=0.0032$ and 0.0225 , respectively, compared with starvation induced apoptosis in control cells). (G) Both IGF-Ir/482st (482) and Ad-IGF-Ir/950st (950) enhanced heat shock $\left(42^{\circ} \mathrm{C}, 1 \mathrm{~h}\right)$ induced apoptosis $1.60(0.03)$ and $1.38(0.01)$ times, respectively, and IGF-Ir/482st was more effective than IGF-Ir/950st ( $p<0.0001, p=0.0031$, respectively, compared with heat-induced apoptosis in controls). Both $260 \mu \mathrm{M}$ 5-fluorouracil (5-FU) (H) and radiation (Radi $30 \mathrm{~Gy}(\mathrm{I})$ ) induced apoptosis. IGF-Ir/482st (482) upregulated the effects of both treatments on apoptosis induction $2.06(0.10)(p=0.0131)$ and $2.18(0.02)$ times $(p<0.0001)$, respectively. The effects of IGF-Ir/950st (950) on both chemotherapy and radiotherapy induced apoptosis were less than those of IGF-Ir/482st (1.96 (0.13) times, $p=0.0264$ and $1.81(0.10), p=0.0229$, respectively). Bars show means (SEM).

Wortmannin enhanced ethanol induced apoptosis in MKN45, but PD98059 and SB203580 had no effect (table 3). In combination with the results of downstream signalling by the western blotting data presented above, these data suggest that the PI3-K/Akt pathway appears to mediate the majority of the antiapoptotic effect of IGFs in gastric malignancies.

\section{IGF-Ir/dn enhances both chemotherapy and radiation induced apoptosis}

To assess the potential of IGF-Ir/dn in combination therapies, MKN45 were treated with chemotherapy or radiation after infection with adenoviruses. Both 5-FU and radiation alone induced caspase- 3 activity (fig $5 \mathrm{H}, \mathrm{I}$ ). In the presence of 


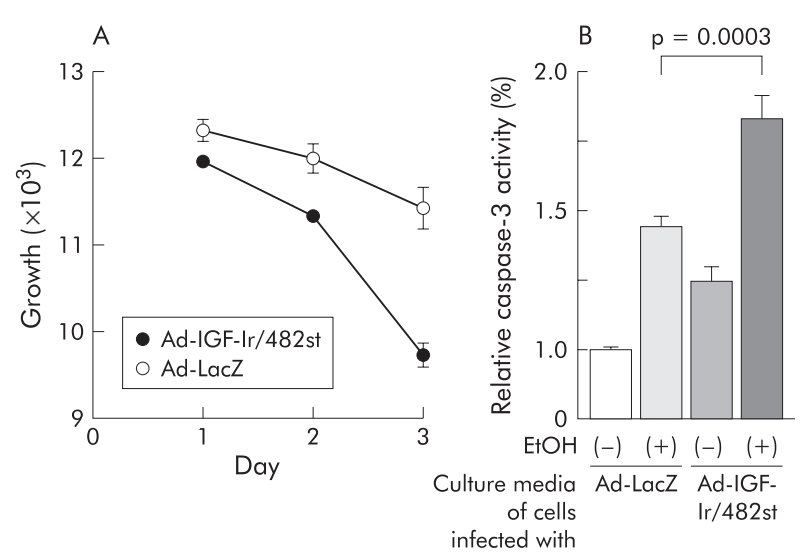

Figure 6 Bystander effects of adenoviruses expressing truncated insulin-like growth factor I receptor of 482 amino acids long (Ad-IGF-Ir/ 482st). After washing, MKN45 cells infected with 30 multiplicity of infection (moi) of Ad-IGF-Ir/482st or Ad-LacZ were cultured with complete medium. Uninfected MKN45 were then cultured with the collected media. (A) Trypan blue assays revealed cell growth suppression by conditioned medium from cells infected with Ad-IGF-Ir/ 482st compared with control media $(p=0.0087)$. (b) Conditioned media from cells infected with Ad-IGF-Ir/482st also enhanced ethanol induced apoptosis by the caspase- 3 assay in MKN45 cells ( $p=0.0003$ compared with ethanol stimulated cells cultured with the media from cells infected with Ad-LacZ (adenovirus expressing $\beta$-galactosidase).

IGF-Ir/dns, both 5-FU and radiation induced caspase-3 activities were increased significantly. The effects of the combinations were greater than addition of the effects of the monotherapies. These results suggest that IGF-Ir may play a critical role in protection from apoptosis induction by both chemotherapy and radiation and that IGF-Ir/dns enhance the effects of both therapies.

\section{IGF-Ir/482st has bystander effects}

To confirm bystander effects of IGF-Ir/482st, we did the following two experiments. MKN45 were infected with Ad-IGF-Ir/482st or Ad-LacZ, after being washed several times with phosphate buffered saline to remove residual input adenovirus. Transduced cells were subsequently cultured for 24 hours and these conditioned media were then transferred to untreated cultures of MKN45. Conditioned medium from cells infected with Ad-IGF-Ir/482st markedly inhibited proliferation compared with controls and resulted in increased ethanol induced apoptosis (fig 6). As expected, media cultured from cells infected with Ad-IGF-Ir/950st had no effect on either proliferation or survival (data not shown). The results demonstrate bystander effects of Ad-IGF-Ir/482st, as predicted.

\section{IGF-Ir signals are essential for in vivo tumorigenicity and $\mathrm{Ad}-\mathrm{IGF}-\mathrm{Ir} / \mathrm{dn}$ causes regression of tumours in mice}

Our results thus far have shown that IGF-Ir is a key molecule for both growth and survival in gastric cancer in vitro, so we next evaluated its role in vivo. At the tumour inoculates used, MKN45 infected with Ad-LacZ formed subcutaneously tumours in all mice. However, cells transduced with Ad-IGF-Ir/482st did not grow (fig 7A). This indicates that IGF-Ir is a key molecule for enabling tumour formation in gastric cancer xenografts and IGF-Ir/482st effectively suppresses in vivo tumorigenicity.

To assess the effects of the truncated receptors on preexisting tumours, MKN45 was inoculated into mice and allowed to form evident tumours. Intratumoral injection of Ad-IGF-Ir/dns resulted in growth retardation of these
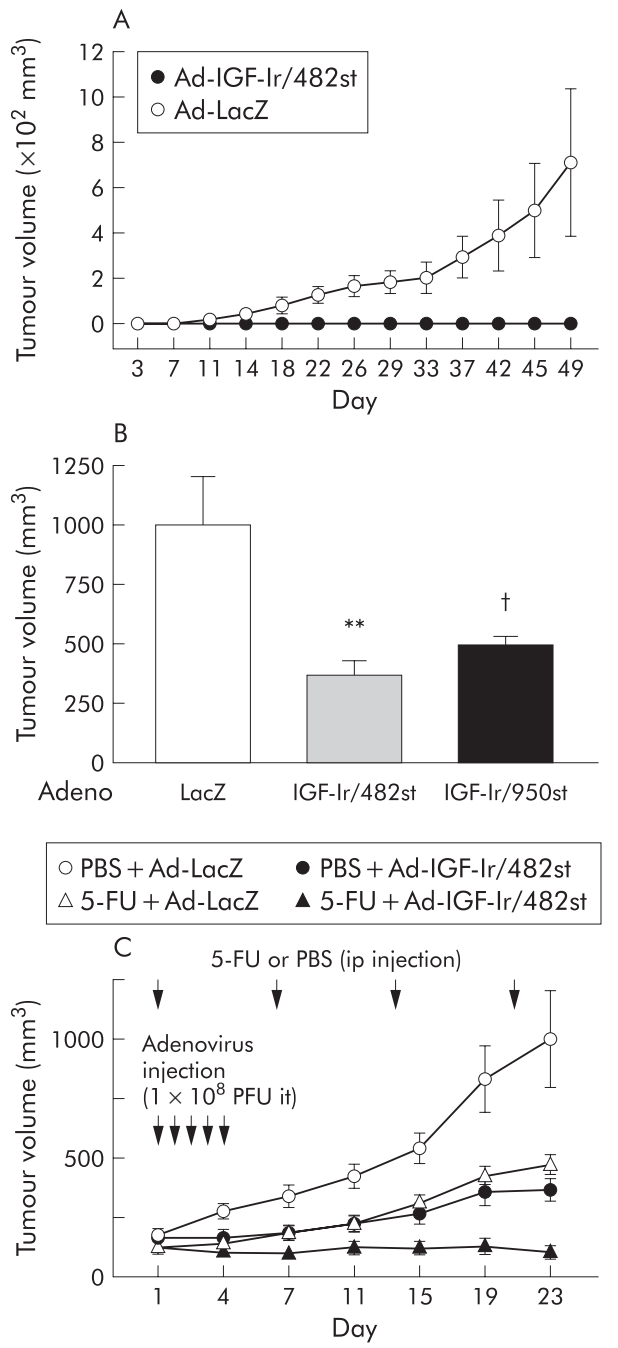

Figure 7 Effects of insulin-like growth factor I receptor (IGF-Ir) on in vivo tumorigenicity and tumour growth. (A) MKN45 cells infected with adenoviruses expressing truncated IGF-Ir of 482 amino acids long (AdIGF-Ir/482st) or adenovirus expressing $\beta$-galactosidase (Ad-LacZ) were inoculated subcutaneously into nude mice ( $n=6$ per group). Although cells infected with Ad-LacZ formed subcutaneously tumours, mean (SEM) size was 870 (347) $\mathrm{mm}^{3}$; after 49 days, cells expressing IGF-Ir/482st did not form any tumours. (B) Established palpable subcutaneously MKN45 tumours (mean (SEM) size $153(13) \mathrm{mm}^{3}$ ) were directly injected with $1 \times 10^{8}$ PFU of adenoviruses on five successive days and tumour volumes measured ( $n=12$ /group). Both Ad-IGF-Ir/dns significantly reduced tumour growth; tumour volume with Ad-LacZ was 1001 (202) $\mathrm{mm}^{3}, 506(29) \mathrm{mm}^{3}$ with adenoviruses expressing truncated IGF-Ir of 950 amino acids long (Ad-IGF-Ir/950st), and 377 (55) $\mathrm{mm}^{3}$ with Ad-IGF-Ir/482st, 21 days after treatment (**IGF-Ir/482st $v$ control, $p=0.0041 ;$ † IGF-Ir/950st $v$ control, $p=0.0257$ ). (C) Combination therapy of 5 -fluorouracil (5-FU $50 \mathrm{mg} / \mathrm{kg}$ ) and IGF-Ir/482st was assessed. After forming subcutaneously MKN45 tumours, $1 \times 10^{8} \mathrm{PFU}$ of Ad-IGF-Ir/482st or Ad-LacZ were injected intratumorally (it) on five successive days and 5-FU or vehicle (phosphate buffered saline (PBS)) was injected (intraperitoneally (ip)) four times, once a week $(n=12$ / group). Both 5-FU alone and IGF-Ir/482st alone suppressed tumour growth ( $p=0.0041$ and 0.0018 , respectively). The combined therapy was the most effective $(p<0.0001$ compared with control) and two tumours were cured.

established tumours 21 days after treatment (fig 7B). These data indicate that Ad-IGF-Ir/dn can significantly suppress the growth of established tumours.

As IGF-Ir/dn upregulates 5-FU-induced apoptosis in vitro, the effect of combined IGF blockade with chemotherapy on tumours in mice was then assessed. Established MKN45 tumours were intratumorally injected with adenoviruses and 


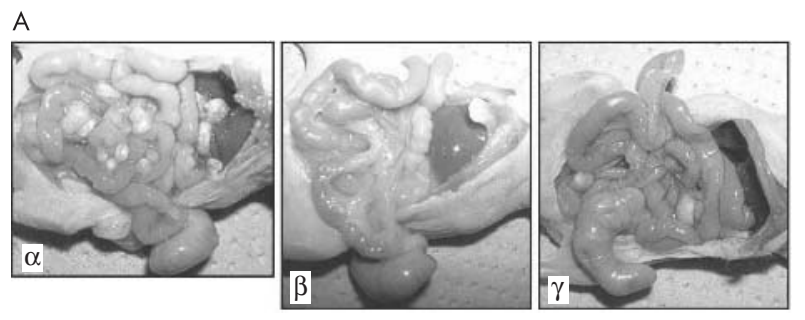

B
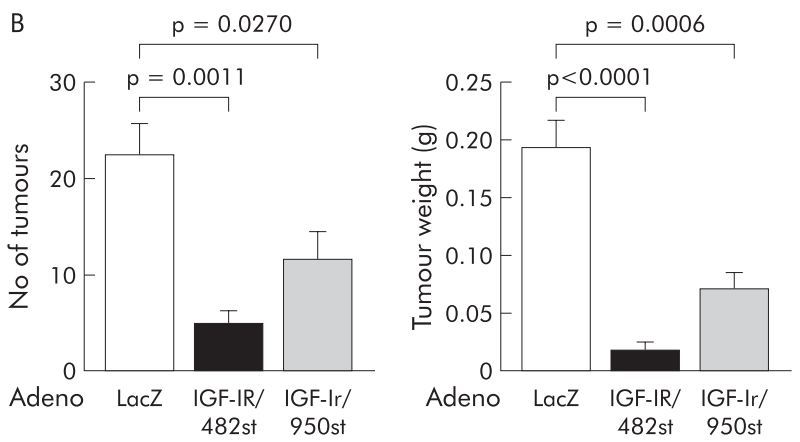

C

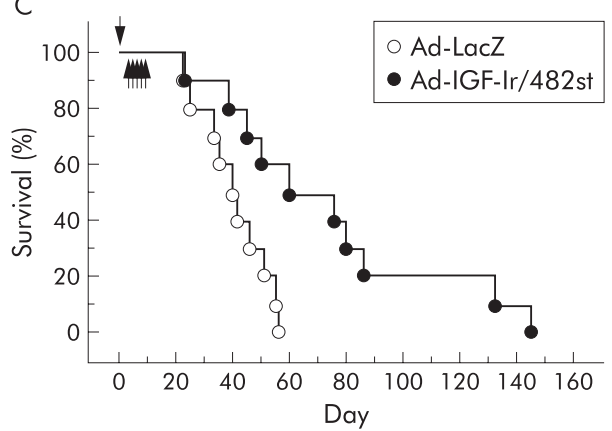

Figure 8 Role of the insulin-like growth factor I receptor (IGF-Ir) axis in intraperitoneal tumour growth. (A) MKN45 tumour cell implants after intraperitoneal injection. Intraperitoneal injection with both adenoviruses expressing truncated IGF-Ir of 482 amino acids long (Ad-IGF-Ir/482st) ( $\beta$ ) and adenoviruses expressing truncated IGF-Ir of 950 amino acids long (Ad-IGF-Ir/950st) ( $\gamma$ ) on five successive days suppressed the number of peritoneal implants, but adenovirus expressing $\beta$-galactosidase (Ad-LacZ) $(\alpha)$ did not $(n=5)$. (B) The dominant negative forms (dns) of IGF-Ir (IGF-Ir/dns) reduced the number of disseminated tumours and IGF-Ir/482st was more effective than IGF-Ir/950st ( $p=0.0011$ and $p=0.0270$, respectively). Tumour burden was also diminished by both IGF-Ir/dns (IGF-Ir/482st, $p=0.0011$; IGF-Ir/950, $p=0.0270$ ). (C) MKN45 cells were injected into the peritoneal cavity on day 0 (arrow) and 10 mice in each group were treated with either Ad-LacZ or Ad-IGF-Ir/482st intraperitoneally from day 4 to 8 (arrows). IGF-Ir/ 482 st prolonged the survival time of MKN45 disseminated mice (log rank test, $p=0.0117$ ).

mice were intraperitoneally injected with 5-FU or phosphate buffered saline. 5-FU or IGF-Ir/482st alone significantly suppressed tumour growth (fig 7C). The combination therapy was much more effective for these pre-existing tumours, two of which were cured completely. This indicates that Ad-IGFIr/482st has significant potential to enhance the effect of chemotherapy in gastric cancer.

\section{IGF-Ir participates in peritoneal dissemination}

A significant clinical problem in gastric cancer is intraperitoneal dissemination and invasion. We therefore investigated the role of IGF-Ir on peritoneal dissemination. MKN45 cells form disseminated nodules after intraperitoneal injection. Mice bearing intraperitoneal MKN45 were treated by intraperitoneal administration of adenoviruses. Ad-IGF-Ir/ dns reduced both number and volume of tumour nodules and IGF-Ir/482st was more potent than IGF-Ir/950st (fig 8A, B). Even after only five days of treatment, Ad-IGF-Ir/482st prolonged survival with median survivals of 60 compared with 39 days (fig 8C). These data show that IGF-Ir plays an important role in intraperitoneal tumour growth and that Ad-IGF-Ir/dn may be an effective strategy for treating peritoneal dissemination.

\section{DISCUSSION}

Gastric carcinoma has a variety of histological types and patients with this disease manifest different clinical courses. It is frequently diagnosed in advanced stages with lymph node metastases, peritoneal dissemination, and hepatic involvement, and there are a paucity of meaningful treatment strategies. IGF mediated growth responsiveness is found in most cancer cells, including the stomach. ${ }^{4}{ }^{18}$ Recent studies have shown that elevation of serum IGF-I increases the risk of developing several cancers. ${ }^{31-33}$ In gastric cancer, aberrant activation of IGF-Ir by paracrine/autocrine loops has been suggested because expression of both IGFs and their receptors are high in tumour tissues. ${ }^{14-16}$ The functional importance of IGF-Ir has been independently demonstrated by tumour cell growth inhibition by an anti-IGF-Ir antibody ${ }^{16}$ Here, we showed that IGF-Ir signal plays a critical role in mitogenesis and survival in three cell lines with different characteristics (for example, histological types and mutation status of p53), suggesting that the IGF-Ir axis may be important in a large fraction of gastric cancers. In this study, we used dn receptor systems delivered by recombinant adenoviruses for accurate dissection of the responsible signalling pathways and evaluation of the effects of controlled and selective IGF-Ir blockade. These Ad-IGF-Ir/ dns suppressed tumorigenicity both in vivo and in vitro, and enhanced chemotherapy and radiation induced apoptosis in vitro and chemotherapeutic efficacy in vivo. Moreover, IGF-Ir/482st produced bystander effects, blocking IGF-Ir mediated signalling even in non-gene modified cells. These results indicate that this strategy is promising for the treatment of gastric cancer both as a monotherapy and in combination with chemotherapy and/or radiation. Primary resistance to chemotherapy is a serious problem in gastric cancer and this approach has the potential for improving this responsiveness.

As IGF-Ir is closely related to the insulin receptor, it is important that any strategy designed to block IGF-Ir signals has specificity for IGF-Ir and does not influence insulin receptor signalling. We showed here that Ad-IGF-Ir/dn does not suppress insulin induced Akt phosphorylation, indicating a high degree of receptor selectivity with this molecular targeted therapy.

Both IGFs are involved in the autocrine/paracrine growth stimulation of gastric tumours. ${ }^{15}$ The initial proliferative switch appears to be correlated with IGF-II and an antisense IGF-II interferes with proliferation. ${ }^{34}$ Moreover, intestinal fibroblasts in addition to cancer produce IGF-II. ${ }^{35}$ We showed that Ad-IGF-Ir/dn can block signalling from both ligands, broadening the potential activity of IGF-Ir/dn as an anticancer therapeutic.

The bioactivity of IGF is modulated by several high affinity IGFBPs. ${ }^{33}{ }^{36}$ Here, IGF-Ir/dn blocked des(1-3)IGF-I-induced Akt phosphorylation. This indicates that IGFBPs are not significantly involved in the effect of IGF-Ir/dn and suggests the stability of this strategy.

The important downstream signalling pathways responsible for the observed effects of the IGFs are a matter of intense investigation. We demonstrated that both wortmannin and PD98059 inhibited proliferation to the same degree as IGF-Ir/ dn but SB203580 did not. Although wortmannin alone 
upregulated ethanol induced apoptosis to a similar degree as IGF-Ir/dn, neither PD98059 nor SB203580 did. The fact that IGF-Ir/dn blocked phosphorylation of Akt-1 and p38, but not the ERKs, indicates that the PI3-K/Akt-l pathway is key in IGF-Ir derived growth and survival signals. In the latter, Bad may be one of the downstream targets through Akt. This interpretation is further supported by the evidence that there is cross talk between IGF-Ir and Akt-l which upregulates IGF-Ir expression. ${ }^{37}$

We also showed that intraperitoneal growth of gastric cancer was very potently inhibited by Ad-IGF-Ir/dns, similar to what we observed in our previous study in pancreatic cancer. ${ }^{25}$ Peritoneal dissemination and locoregional recurrence after resection are significant clinical problems for which there are no effective treatments in both cancers. Prevention and/or treatment of peritoneal dissemination may be an important therapeutic strategy for improving the quality and quantity of life for gastric cancer patients.

IGF-Ir plays a critical role in gastric cancer progression and is a strong candidate as a molecular therapeutic target. IGF-Ir/dn suppresses tumorigenicity and upregulates apoptosis by blocking Akt activation. Ad-IGF-Ir/dn also potentiates radiation and chemotherapy and reduces intraperitoneal dissemination. These studies thus validate IGF-Ir as a therapeutic target in this disease and suggest that adenovirus-IGF-Ir/482st may be a promising anticancer therapy for gastric carcinoma.

\section{ACKNOWLEDGEMENTS}

This work was supported by grants-in-aid from the Ministry of Education, Culture, Sports, Science, and Technology, the Ministry of Health, Labour and Welfare, Japan, and the Vanderbilt SPORE in Lung Cancer, CA90949.

\section{Authors' affiliations}

Y Min*, Y Adachi*, H Yamamoto, A Imsumran, Y Arimura, T Endo,

K Imai, First Department of Internal Medicine, Sapporo Medical

University, Sapporo, Japan

Y Hinoda, Department of Clinical Laboratory Science, Yamaguchi

University School of Medicine, Ube, Japan

C-T Lee, S Nadaf, D P Carbone, Vanderbilt-Ingram Cancer Center and Departments of Medicine and Cell Biology, Vanderbilt University, Nashville, Tennessee 37232-6838, USA

${ }^{*} Y$ Min and $Y$ Adachil contributed equally to this work.

Conflict of interest: None declared.

\section{REFERENCES}

1 Sara VR, Hall K. Insulin-like growth factors and their binding proteins. Physiol Rev 1990;70:591-614.

2 Ullrich A, Gray A, Tam AW, et al. Insulin-like growth factor I receptor primary structure: comparison with insulin receptor suggests structural determinants that define functional specificity. EMBO J 1986;5:2503-12.

$3 \mathrm{Yu}$ H, Rohan T. Role of the insulin-like growth factor family in cancer development and progression. J Natl Cancer Inst 2000;92:1472-89.

4 Baserga R. The IGF-I receptor in cancer research. Exp Cell Res 1999;253:1-6.

5 Baserga R. The insulin-like growth factor I receptor: a key to tumor growth? Cancer Res 1995;55:249-52.

6 Sell C, Rubini M, Rubin R, et al. Simian virus 40 large tumor antigen is unable to transform mouse embryonic fibroblasts lacking type 1 insulin-like growth factor receptor. Proc Natl Acad Sci U S A 1993:90:11217-21.

7 Baserga R. Oncogenes and the strategy of growth factors. Cell 1994;79:927-30.

8 Liu JP, Baker J, Perkins AS, et al. Mice carrying null mutations of the genes encoding insulin-like growth factor I (lgf-1) and type 1 IGF receptor (lgfl r). Cell 1993:75:59-72.

9 Han VK, Lund PK, Lee DC, et al. Expression of somatomedin/insulin-like growth factor messenger ribonucleic acids in the human fetus: identification characterization, and tissue distribution. J Clin Endocrinol Metab 1988;66:422-9.

10 Tremblay E, Chailler P, Menard D. Coordinated control of fetal gastric epithelial functions by insulin-like growth factors and their binding proteins. Endocrinology 2001;142:1795-803.

11 Coerper S, Wolf S, von Kiparski S, ef al. Insulin-like growth factor I accelerates gastric ulcer healing by stimulating cell proliferation and by inhibiting gastric acid secretion. Scand J Gastroenterol 2001;36:921-7.

12 Lee DY, Yang DH, Kang CW, et al. Serum insulin-like growth factors (IGFs) and IGF binding protein (IGFBP)-3 in patients with gastric cancer: IGFBP-3 protease activity induced by surgery. J Korean Med Sci 1997;12:32-9.

13 Franciosi CM, Piacentini MG, Conti M, et al. IGF-1 and IGF-1BP3 in gastric adenocarcinoma. Preliminary study. Hepatogastroenterology 2003:50:297-300.

14 Shiraishi T, Mori M, Yamagata M, et al. Expression of insulin-like growth factor 2 mRNA in human gastric cancer. Int J Oncol 1998;13:519-23.

15 Yi HK, Hwang PH, Yang DH, et al. Expression of the insulin-like growth factors (IGFs) and the IGF-binding proteins (IGFBPs) in human gastric cancer cells. Eur J Cancer 2001:37:2257-63.

16 Pavelic K, Kolak T, Kapitanovic S, et al. Gastric cancer: the role of insulin-like growth factor 2 (IGF 2) and its receptors (IGF IR and M6-P/IGF 2R). J Pathol 2003;201:430-8

17 Ajisaka H, Fushida S, Yonemura $Y$, et al. Expression of insulin-like growth factor-2, c-MET, matrix metalloproteinase-7 and MUC-1 in primary lesions and lymph node metastatic lesions of gastric cancer. Hepatogastroenterology 2001;48:1788-92.

18 Thompson MA, Cox AJ, Whitehead RH, et al. Autocrine regulation of human tumor cell proliferation by insulin-like growth factor II: an in-vitro model. Endocrinology 1990;126:3033-42.

19 Prager D, Li HL, Asa S, et al. Dominant negative inhibition of tumorigenesis in vivo by human insulin-like growth factor I receptor mutant. Proc Natl Acad Sci U S A 1994;91:2181-5.

20 Burgaud JL, Resnicoff M, Baserga R. Mutant IGF-I receptors as dominant negatives for growth and transformation. Biochem Biophys Res Commun 1995;214:475-81

21 Li S, Resnicoff M, Baserga R. Effect of mutations at serines 1280-1283 on the mitogenic and transforming activities of the insulin-like growth factor I receptor. J Biol Chem 1996;271:12254-60.

22 D'Ambrosio C, Ferber A, Resnicoff M, et al. A soluble insulin-like growth factor I receptor that induces apoptosis of tumor cells in vivo and inhibits tumorigenesis. Cancer Res 1996;56:4013-20.

23 Dunn SE, Ehrlich M, Sharp NJ, et al. A dominant negative mutant of the insulin-like growth factor-l receptor inhibits the adhesion, invasion, and metastasis of breast cancer. Cancer Res 1998;58:3353-61.

24 Adachi Y, Lee CT, Coffee K, et al. Effects of genetic blockade of the insulin-like growth factor receptor in human colon cancer cell lines. Gastroenterology 2002; 123:1191-204.

25 Min Y, Adachi Y, Yamamoto H, et al. Genetic blockade of the insulin-like growth factor-I receptor: a promising strategy for human pancreatic cancer. Cancer Res 2003;63:6432-41.

26 Lee CT, Park KH, Adachi Y, et al. Recombinant adenoviruses expressing dominant negative insulin-like growth factor-I receptor demonstrate antitumor effects on lung cancer. Cancer Gene Ther 2003;10:57-63.

27 Hana V, Murphy U. Expression of insulin-like growth factors and their binding proteins in the estrogen responsive Ishikawa human endometrial cancer cell ine. Endocrinology 1994;135:2511-16.

28 Quinn KA, Treston AM, Unsworth EJ, et al. Insulin-like growth factor expression in human cancer cell lines. J Biol Chem 1996;271:11477-83.

29 Bredin CG, Liu Z, Hauzenberger D, et al. Growth-factor-dependent migration of human lung-cancer cells. Int J Cancer 1999;82:338-45.

30 Jia LQ, Osada M, Ishioka C, et al. Screening the p53 status of human cell lines using a yeast functional assay. Mol Carcinog 1997;19:243-53.

31 Chan JM, Stampfer MJ, Giovannucci E, et al. Plasma insulin-like growth factor-I and prostate cancer risk: a prospective study. Science 1998;279:563-6.

32 Hankinson SE, Willett WC, Colditz GA, et al. Circulating concentrations of insulin-like growth factor-l and risk of breast cancer. Lancet 1998;351:1393-6.

$33 \mathrm{Ma} \mathrm{J}$, Pollak MN, Giovannucci E, et al. Prospective study of colorectal cancer risk in men and plasma levels of insulin-like growth factor (IGF)-I and IGFbinding protein-3. J Natl Cancer Inst 1999:91:620-5.

34 Christofori G, Naik P, Hanahan D. A second signal supplied by insulin-like growth factor II in oncogene-induced tumorigenesis. Nature 1994;369:414-18

35 Simmons JG, Pucilowska JB, Lund PK. Autocrine and paracrine actions of intestinal fibroblast-derived insulin-like growth factors. Am J Physiol 1999;276:G817-27.

36 Guo YS, Beauchamp RD, Jin GF, et al. Insulinlike growth factor-binding protein modulates the growth response to insulinlike growth factor 1 by human gastric cancer cells. Gastroenterology 1993;104:1595-604.

37 Tanno S, Mitsuuchi Y, Altomare DA, et al. AKT activation up-regulates insulinlike growth factor I receptor expression and promotes invasiveness of human pancreatic cancer cells. Cancer Res 2001;61:589-93. 